\title{
Preclinical and Clinical Studies of Lapachol and Beta-Lapachone
}

\author{
Edvaldo Rodrigues de Almeida*
}

Center of Biological Science, Department of Antibiotics, Federal University of Pernambuco, (UFPE), Recife, Pernambuco Brazil, Post code 50670-901 Brazil

\begin{abstract}
Lapachol whose isolation and study at the end of the century by Parternó, is one of the most brilliant chapters of Phytochemistry, especially in conjunction with the work of Max Siewert a communication on the wood of the Argentina Lapachol (Bignoniaceae) tree from Max Siewert, submitted along with Ricardo Napp in Exp. NAC. Philadelphia in 1876. The Lapachol has its origin in the Tabebuia avellanedae Lorentz ex. Griseb (Bignoniaceae) which in Brazil is known as Pau D'Arc, Ipê-purple, Ipê-Black, and Yellow-Ipê. It is a tree of huge size used in traditional medicine for cases of stomatitis, inflammatory processes in general and against cancer. $\beta$-Lapachone is an o-naphthoquinone from Lapachol used against, Trypanosome cruzi, cancer, viruses, bacteria, and leishmania is currently evaluated. This plant can also be found in other plant families such as, Verbenaceae Leguminosae, Sapotaceae, Scrophulariaceae, Malvaceae and Proteaceae. This paper aims at demonstrating the pharmacology and clinical activity of Lapachol and $\beta$-Lapachone, through their mechanism of action, and other actions which are not related to their anti neoplastic activity.
\end{abstract}

Keywords: Lapachol, $\beta$-lapachone, preclinical and clinical studies, cancer.

\section{INTRODUCTION}

Lapachol is a natural naphthoquinone obtained from the Tabebuia avellanedae Lorentz ex. Griseb (Bignoniaceae) from which Lapachone can be derived [1]. The Lapachol in Brazil is known as Pau D'Arc, Ipê-purple, Ipê-Black, and Yellow-Ipê. It is a tree of great size. Its use in traditional medicine is indicated for cases of stomatitis, inflammatory processes in general and against cancer [2, 3]. Lapachol has been known since 1858, and found as a component of various plants of the family Bignoniaceae, Verbenaceae Leguminosae, Sapotaceae, Scrophulariaceae Malvaceae, and Proteaceae. $[4,5]$. However, this occurrence is higher in the Bignoniaceae family, particularly in the gender Tabebuia, along with other heterocyclic quinones. Initial studies conducted in the Department of antibiotics, Federal University of Pernambuco in 1973 demonstrated strong action against gram positive bacteria [6-7]. In recent years, the interest in this group of quinones has grown because of their importance in biochemical processes mainly in the levels of respiratory chain [8]. The Lapachol, which was isolated and studied at the end of the century by Parternó, is one of the most brilliant chapters of Phytochemistry. It was originally isolated from Tabebuia avellanedae (Bignoniaceae) and $\beta$ Lapachol and has its origin in the Lapachol. Currently, there has been a rapid increase in information available on these compounds in the scientific literature [9].

\section{ANTI-NEOPLASTIC EFFECTS OF LAPACHOL AND B-LAPACHONE}

In 1966, Gonçalves de Lima et al. obtained the xiloidone from lapachol in the presence of pyrimidine. It is since 1952

*Address correspondence to these authors at the Department of Antibiotics, Federal University of Pernambuco. Post Code 50670-901 Recife, Pernambuco, Brazil; Tel: +55 81 21268346; Fax: +55 81 21268346;

E-mail: edvaldo.ra@gmail.com that Dr Osvaldo Gonçalves de Lima and coworkers have studied the anti-tumoral effect of Lapachol by demonstrating significant activity against cancerous tumors in rats and human patients $[6,10,11]$. In 1966, the group of Gonçalves de Lima isolated and identified xiloidone in the presence of the pyrimidine [12]. In 1980, pure Lapachol demonstrated its ability to shrink tumors and reduce pain caused by tumors in patients affected by various types of cancers (liver, kidney, breast, prostate and cervix), and achieved complete remissions in three of the patients [10,13]. It is believed that the antitumor activity of Lapachol may be due to its interaction with nucleic acids. The $\beta$-Lapachone presents the ability to induce apoptosis in HepG2 hepatoma line cells through the induction of Bax and activation of caspase [14, 15]. It demonstrated the ability of tumor inhibition by $\beta$-lapachoneactivated nuclear factor- $\kappa \mathrm{B}$ transcription factor, activator protein-1 and c-jun $\mathrm{N}$-terminal kinases, and thus promotes the apoptosis of tumor cells. Beta-lapachone showed the ability to inhibit tumor promoting apoptosis through nuclear factor-activated transcription factor- $\mathrm{\kappa} \mathrm{B}$, activator protein-1 and c-jun N-terminal kinases [16, 17]. Additionally, it has been proposed that interaction of the naphthoquinone moiety between base pairs of the DNA helix occurs with subsequent inhibition of DNA replication and RNA synthesis. Although Lapachol has some beneficial effects, it is by no means a perfect anticancer drug. Despite the absence of significant toxicity even at high doses, the plasmatic concentrations are too low to demonstrate a therapeutic effect. Because of its antitumor activity, it is an ideal candidate for systematic modification to develop an understanding of its structureactivity relationship and thus eventually to develop analogs with improved activity and pharmacokinetic profile [18]. Fig. (1) in this context, the results obtained with some derivative of the 1,4-naphthoquinone on experimental tumors are promising [19]. 


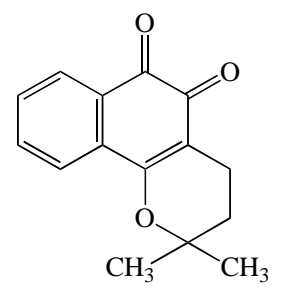

Beta-Lapachone

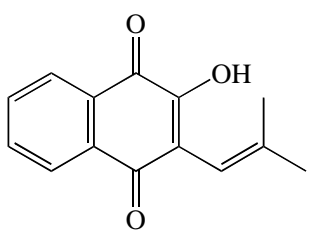

Lapachol
Fig. (1). Beta-lapachone: 3, 4-Dihydro-2, 2-dimethyl-2H-naphtho (1, 2-b) pyran-5, 6-dione and lapachol: 2-Hydroxy-3-(3-methyl2butenyl) 1, 4-naphthoquinone.

\section{INHIBITION OF METASTASIS BY LAPACHOL}

A study aiming at studying the effects of Lapachol on a human cancer cell line and at evaluating its potential as an anti-metastatic drug using an in vivo assay has been performed. The results indicated that Lapachol, in the maximal non-toxic concentration for HeLa cells $400 \mu \mathrm{g} / \mathrm{mL}$ (corresponding to 1012 molecules of the drug/cell), induces alterations in the protein profile and inhibits cellular invasiveness, thus representing an important anti-metastatic activity [20, 21].

\section{OTHER ACTIONS OF LAPACHOL AND $\beta$ - LAPACHONE NOT RELATED TO THEIR ANTI- NEOPLASTIC ACTION}

Lapachol, as other naphthoquinones, interferes with the electron transport and inhibits the cells through the respiratory chain $[22,23]$. One study found that the Lapachol at a concentration of $100 \mathrm{mg} / \mathrm{mL}$ inhibits the absorption of oxygen in the Plasmodium knowlesi in $74 \%$ and the system of succinate oxidase in $26 \%$. These findings lead to the conclusion that Lapachol displays antimalarial activity against Plasmodium lapohurae via respiration inhibition as a likely mechanism of action. The hypothesis is that Lapachol inhibits the interaction between the cytochromes $\mathrm{b}$ and $\mathrm{c}$, or directly inhibits an enzyme between the two cytochromes [5]. It was shown that Lapachol has activity against Helicopter pylori, Staphylococcus, Streptococcus, Enterococcus, Bacillus and Clostridium species with an MIC ranging from 1.56 to $25 \mathrm{mg} / \mathrm{mL}$. In addition, it was reported that Lapachol has a significant effect against Candida albicans, Candida tropicalis, and Cryptococcus neoformans, which was similar to Amphotericin B. The presumed anti fungal activity of Lapachol is believed to be due to its interaction with the cellular membrane and recent studies showed an activity against the fungus Candida elegans [24-26]. Studies conducted by researchers in 1978, 2001 and 2008, demonstrated the action of trypanocidal Lapachol and $\beta$-lapachone by evaluating their action in vitro and in vivo $[27,28]$. On the other hand, was demonstrated the inhibitory action of Lapachol against Epstein-Barr and HIV virus, its action is probably through training species active oxygen $\left(\mathrm{O}_{2}\right.$ and $\left.\mathrm{H}_{2} \mathrm{O}_{2}\right)$, or through the membrane

Derivatives synthesized from the naphthoquinone lapachol, were tested for their inhibitory effects on Epstein-Barr virus early antigen (EBV-EA) activation, induced by 12-Otetradecanoylphorbol-13-acetate (TPA), as a test for potential cancer chemopreventive agents [29].
Transcription of type 1 human immunodeficiency virus (HIV-1) provirus is governed by the viral long terminal repeat (LTR). Drugs can block HIV-1 replication by inhibiting activity of its LTR. It was reported that topotecan, betalapachone, and curcumin are potent and selective inhibitors of HIV-1 LTR-directed gene expression, at concentrations that have minor effects on cells. [30]. The Lapachol was shown to be active against herpes virus types I and II. The mechanism of the action of these quinones is supposed to involve inhibition of DNA and RNA polymerase and retrovirus reverse transcriptase. Moreover, $\beta$-Lapachone is presumed to interfere with the replication of HIV-1 through transcriptase inhibition. It is reported that Lapachol decreases the replication of the virus in humans, although no clinical data is available [30]. Moreover, Lapachol presented in vitro an antipsoriatic effect [31]. The Lapachol presented an anti-inflammatory effect at doses 100 and $150 \mathrm{mg} / \mathrm{kg}$, using the model of oedema of paw and induction carrageen in-induced abscess. The Lapachol promoted an inhibition of oedema of paw of 76 and $85 \%$ respectively, and an inhibition of abscess using the same doses in 38 and $57 \%$ respectively, evaluated by abscess wet weight (g) [32]. In a toxicological evaluation of Lapachol in pregnant rat's exophthalmia, leporine lip, abdominal cavity organs out side for both doses, were demonstrated [33]. In 2001, leishmanicidal activity in vitro of Lapachol had already been cited. Meanwhile, in 2004, the results obtained in vitro were confirmed working by amastigotes [34]. However, a characteristic of Lapachol and $\beta$-Lapachone is that they interfere with the oxygen metabolism generating oxygen free radicals. This is probably the mechanism of the action of Lapachol and $\beta$-Lapachone on these organisms. Lapachol was evaluated on the basis its activity against Molluscicidal Biomphalaria glabrata and showed significant Molluscicidal activity $[35,36]$. Some of the synthesized derivatives of Lapachol led to a higher molluscicidal activity than that of Lapachol. These findings confirm the importance of Lapachol as a starting material for the production of biologically active compounds $[36,37]$.

\section{NAPHTHOQUINONES}

Natural quinones have their importance for the plants mentioned above, through their actions against arthropods, fungi, liquens, bacteria, viruses and algae. In studies with quinones a variety of bioactive actions were shown, mainly against bacteria, parasites, and virus. Their mechanism of action is through the formation of oxygen species $\left(\mathrm{O}_{2}\right.$ and $\mathrm{H}_{2} \mathrm{O}_{2}$ ) [38-39]. Recently, activity through the inhibition of topoisomerase I and II, promoting cellular apoptosis was observed. Currently, there is considerable interest in getting knowledge on the pharmacology and on the mode of action of these substances, as it can be demonstrated by the growing number of publications on the mechanism of action of Lapachol and $\beta$-lapachone [40].

\section{MECHANISM OF ACTION OF LAPACHOL AND B- LAPACHONE}

\section{Redox Cycle}

An oxidative stress promoted by Lapachol was demonstrated. This effect is through P450 reductase enzyme forming reactive species of oxygen and consequently the loss of DNA (Fig. 2). The $\beta$-lapachone, derived from Lapachol, 
<smiles>COC1=C(CC=C(C)C)C(=O)c2ccccc2C1=O</smiles>

Fig. (2). 2-methoxylapachol.

shares some similarities with other natural naphthoquinones. This ortho-pyranonaphthoquinone also has a part in the action involving the redox cycle $[41,42]$. The term "apoptosis" describes an active process of cellular deconstruction originally contrasted morphologically with necrosis. It is a form of cell death that occurs during several physiological and pathological situations in multicellular organisms, which constitutes a common mechanism of cell replacement, tissue remodeling, and removal of damaged cells. Apoptosis is a complex process characterized by cell shrinkage, chromatin condensation, internucleosomal DNA fragmentation, and formation of "apoptotic bodies," since proliferation and apoptosis are intimately linked. Some cell cycle regulators can influence both cell division and programmed cell death [43].

The reversible phosphorylation of proteins controlled by protein kinases and protein phosphatase is a major mechanism that regulates a wide variety of cellular processes including cell death [44]. Several protease families are also implicated in apoptosis, the most prominent being Caspar, which are $\mathrm{N}$-acetyl-cysteine containing aspartic acid-specific proteases that exist as zymogene in the soluble cytoplasm, mitochondrial intermembrane space, and nuclear matrix of virtually all cells. Apoptosis is a subject of intense research since it has been found that tumor cells, including leukemia and lymphoma cell lines undergo this kind of cell death in response to anti-tumor agents [45].

The main interest in quinones is due to their ability to induce oxidative stress in cells. It is likely that a low percentage of oxygen consumed by mammals is converted into $\mathrm{O}_{2}$ and $\mathrm{H}_{2} \mathrm{O}_{2}$, due to flaws in cell respiration. The imbalance between the generation and the removal of free radicals can lead to a pro-oxidant status and to cellular death. Studies have shown that the extracellular $\mathrm{Ca}^{2+}$ chelator, EGTA, later inhibited apoptotic, suggesting that later execution events were triggered by $\mathrm{Ca}^{2+}$ influxes from the extracellular milieu [46].

Altogether, these data suggest a critical, but not a sole, role of $\mathrm{Ca}^{2+}$ in the NQO1-dependent cell death pathway initiated by $\beta$-Lapachone [46-47]. The use of $\beta$-Lapachone to trigger an apparently novel calpain-like mediated apoptotic cell death could be useful for breast and prostate cancer therapy. A demonstrated synergism between genistein and $\beta$ Lapachone justifies consideration of these phytochemicals in chemotherapeutic strategic planning. The cytotoxic activity of amino (3a-e), aza-1-antraquinone (4a-e) lapachol derivatives against Ehrlich carcinoma and human K562 leukemia cells was investigated. Significant inhibitory activities were observed for $3 \mathrm{a}-\mathrm{d}$ at $200 \mu \mathrm{M}$, and a partial inhibitory action was observed for lapachol and methoxylapachol (Fig. 2) [48, 49].

\section{SIGNS OF CELL DEATH BY APOPTOSIS AND OXI- DATIVE STRESS}

Current evidence suggests that there are several routes for the capase activation, depending on the stimulus that triggers the machinery of death, and in general, two distinct paths may be active.

The apoptosis initiated by recipients of death such as Fas, also called CD95 or Apo-1 and TNF-R1 (Tumor necrosis factor), requires pro-caspase- 8 or -10 in the complex 46]. A wide variety of stimuli can induce apoptosis, among them is oxidative stress caused by the generation of oxidative intermediaries through the action of some anti-cancers [46-48]. The mechanism may be induced by exposure to hydrogen peroxide, cyclization-redox of quinones or thio-alkylating agents. A huge amount of data supports the role of oxidative stress in triggering apoptosis, which classically involves a moderate accumulation of reactive oxygen species [44].

The oxidative stress may inhibit or promote apoptosis and even necrosis (Fig. 3), depending on the intensity of the stimulus. The cytotoxic activity of amino (3a-e), aza-1antraquinone (4a-e) lapachol derivatives against Ehrlich carcinoma and human K562 leukemia cells was investigated

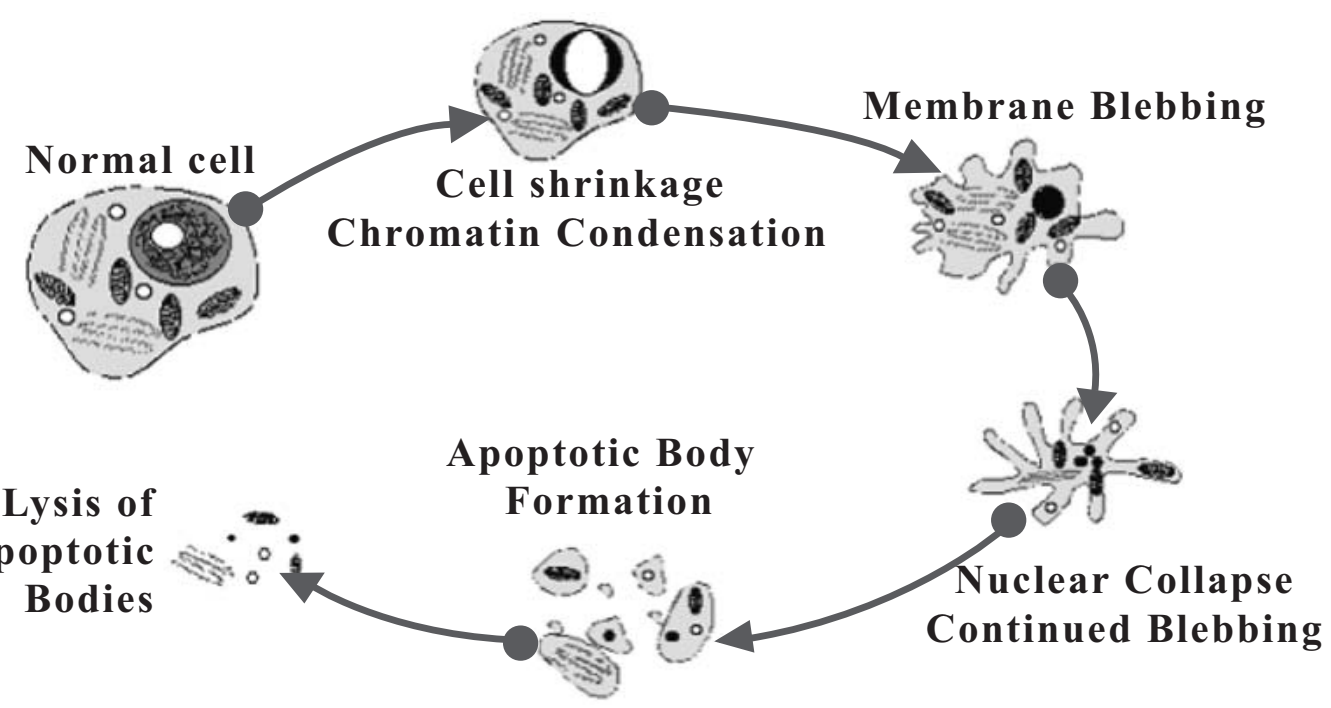

Fig. (3). The process of apoptosis (Programmed Cell Death). 
and significant inhibitory activities were observed for $3 a-d$ at 200 [50].

\section{B-LAPACHONE: OTHER ACTIONS}

$\beta$-lapachone, the quinine, derived from lapachol (a naphthoquinones) can be isolated from the lapachol tree. The camptothecin, topotecan, and $\beta$-lapachone inhibit topoisomerase I and II. It was investigated that the cytotoxic activity of amino derivative of lapachol against Ehrlich carcinoma and human K562 Leukemia cells showed significant inhibitory activities, observed by lapachol and methoxylapachol [50]. Lapachol topoisomerase inhibitors, including $\beta$ Lapachone, seem to be effective against several types of cancers, including lung, breast, colon and prostate cancers and melanoma [51].

Recent research suggests the potential of Lapachol against cancer, specially due to a remarkable synergistic action of $\beta$-Lapachone and Taxol, against several cell lines of tumors implanted in mice [52-54].

It was shown that the action of $\beta$-lapachone inhibits the proliferation and induces apoptosis in retinoblastoma cell lines. Also, their studies showed the synergistic mechanisms of interaction of $\beta$-lapachone radiation with uranium-145 to kill the cancer cells in the treatment of prostate cancer in humans, demonstrated that the antineoplastic action of beta increased when combined with ionizing radiation [55-58, 60, $61]$.

$\beta$-lapachone also interferes with the replication of HIV-1 like camptothecin and topotecan, $\beta$-Lapachone inhibiting DNA [30, 62, 63]. The extracts of Stereospermum suaveolens showed reproducible activity against the Walker 256 intramuscular tumor system. The active principle was isolated and shown to be identical with the known compound lapachol, 2-hydroxy-3-(3-methyl-2-butenyl)-1, 4-naphthoquinone. Lapachol shows significant activity against Walker 256 carcinosarcoma when given intraperitoneally, subcutaneously, intramuscular, and per oral. The best activity and therapeutic indexes are shown when the drug is given twice daily orally $[64,65]$.

Studies have shown the action of Lapachol against Sarcoma of Yoshida and Walker 256 Carcinosarcoma, an inhibition of 82 and $50 \%$, without obtaining any side effects using Wistar rats at a dose of $100 \mathrm{mg} / \mathrm{kg}$, (i.p.) respectively, and determined the LD50 of Lapachol and $\beta$-Lapachone to be $1.6 \mathrm{mg} / \mathrm{kg}$ and $80 \mathrm{mg} / \mathrm{kg}$, respectively [65]. Studies conducted in 2006 showed the involvement of NO/cGMP signaling in the asymptotic and anti-angiogenic effects of $\beta$ lapachone on endothelial cells in vitro (1970) and assessed the anti-cancer potential of these drugs on human neuroendocrine tumor cell lines [66, 67]. In 2005 and 2006, the efficacy of beta-lapachone in the treatment of pancreatic cancer, exploiting a novel therapeutic target NQO1, was assessed [68].

In 2001, the antinociceptive properties, antiedematogenic and acute toxicity of bark aqueous extract of Tabebuia avellanedae was assessed in Wistar rats and mice, and in 2006 the analgesic and non-inflammatory activity of aqueous and hydro alcoholic extracts of the bark, leaves and flowers of Tabebuia impetiginosa Ipê roxo [69] were evaluated. Studies with Tabebuia avellanedae extracts show that it inhibits IL- 2-independent T-lymphocyte activation and proliferation $[70,71]$. Meanwhile, the LD50 of $\beta$-lapachone was determined between 50 and $60 \mathrm{mg} / \mathrm{kg}$ [69] and in 1970 other authors (1970) determined the LD50 of Lapachol at $2.4 \mathrm{~g} / \mathrm{kg}$ in albino rats [65]. Clinical studies in patients with adenocarcinoma of the liver, breast, and prostate, as well as squamous cell carcinoma of the floor of the mouth and the cervix, using a dose of 20 and $30 \mathrm{mg} / \mathrm{kg}$, orally, in four administrations, showed a temporary reduction of injuries and a decrease in pain during the treatment of patients [11].

In pharmacodynamic preparations, a change in blood pressure, respiration, and in the small intestine of guinea pig (Cavia porcellus) was not evident [65]. In the toxicological study of $\beta$-lapachone, its action in pregnant rats and nonpregnant rats, and chronic treatment in the male rats for 21 days for histological evaluation of organs, was evaluated.

The results were as follows: The $\beta$-lapachone promoted alteration in the spleen structure of the experimental group and showed enlarged follicles in the white pulp when compared with the control group. A relatively high frequency of hypertrophy in the follicles mantle zone, as well as in the perifollicular (marginal) zone was observed. No changes in liver structure were observed in the experimental animals. Under light microscopy, the parenchyma (hepatocytes) and stroma components were well preserved. The $\beta$-lapachone did not produce histological alterations in the kidneys of the animals of the experimental group [73].

\section{DISCUSSION}

The investigations of the therapeutic effects of Lapachol began in the sixties. In 1970, the National Cancer Institute concluded that high doses are needed to achieve anticancer effect resulting in high side effects in patients, after some research on the effectiveness of anti neoplastic Lapachol. These data caused the suspension of further studies on this action. However, remarks about the side effects of Lapachol encouraged researchers to develop Lapachol derivatives through the structure-activity relationship based on the molecular structure of Lapachol. At this stage, there was the synthesis of various analogs of Lapachol possessing great activities $[71,72]$. As an example we can cite the $\beta$ Lapachone which presents a varied bioactive action, particularly against prostate cancer and others [14, 30, 31, 34, 49] However, there is a difference between the LD50 of $\beta$ lapachone and lapachol, when comparing the results of 1970 $[65,67,71]$. These data can be related to the purity of the drugs studied. Given the foregoing, it is necessary to standardize the LD50 of Lapachol and $\beta$-lapachone. Furthermore, the analgesic actions obtained in animals are in agreement with data obtained by Santana in their clinical studies where a decrease of the tumor and absence of pain in patients treated occurred [65]. Similar results obtained with lapachol and $\beta$-lapachone are also promising future therapeutic agents $[8,19,20,66,68,70]$. Another important fact regarding the lapachol and $\beta$-lapachone is their mechanism of action in cellular level, specially against cancer cells, which are well documented in the literature [23, 42, 47]. The data obtained in the spleen and the immune-competent cells of the blood can be another action of the $\beta$-lapachone against cancer cells. The significant increase of Gamma GT, GPT, and AP levels can explain the damages in the liver, mainly in 
the biliary duct, when associated with the increase in total bilirubin in sanguineous circulation, an effect that was not observed in the histology. In the histology and in the biochemical data of the kidney (creatinine and urea) no alteration was observed in the treatment with $\beta$-lapachone at the doses administered [73]. The data in the histology of spleen and the increase in the white cells of the blood, can possibly indicate a new action of $\beta$-lapachone as an immunostimulant; however, more research must be conducted to better understand this action [73]. Given the data obtained in literature which presents some contradictions on the action of both drugs, initially the actions of antitumor Lapachol in preclinical studies are not in agreement with data obtained in the clinical study. In addition, the LD50 of both drugs, from our point of view, should be reviewed within analytical standards and rigidity.

\section{ACKNOWLEDGEMENT}

The author wish to express his gratitude to the Federal University of Pernambuco - Brazil for support during this review.

\section{REFERENCES}

[1] Partenó, E. Ricerche sull's acido lapacico. Gazz. Chim. Ital., 1882, $12,337$.

[2] Gonçalves de Lima, O.; D’Albuquerquer, I.L. Primeiras observações sobre a ação antimicrobiana do Lapachol. Rev. Inst. Antibiót., 1956, 4(1/2), 12.

[3] Almeida, E.R. Plantas Medicinais Brasileiras conhecimentos populares e científicos. 1 rd ed.; Hemus Press: São Paulo Brasil, 1993.

[4] Mahler, R.H.; Lordes H.E. Biological Chemistry, $2^{\text {nd }}$ ed.; Herper International Edition: London, 1971.

[5] Hussain, H.; Krohn, K.; Ahmad, V.U.; Miana, G.A.; Green, I.R. Lapachol: an overview. Arkivoc, 2007, (ii), 145-171.

[6] Gonçalves de Lima, O.; Weigert, E. Atividade antimicrobiana e antineoplásica de Juglona, Lapachol e Plumbagina. Rev. Ints. Antibiót., 1972, 12(1/2), 3-12.

[7] Nagata, K.; Kei-Ichi, H.; Koyama, J.; Wada, Y.; Tamura, T. Antimicrobial activity of novel furanonaphthoquinone analogs. Antimicrob. Agents Chemother., 1998, 42(3), 700.

[8] Murray, M.T.; Pizzorno, J.E. Encyclopedia of Natural Medicine, $2^{\text {nd }}$ ed.; PA4 Rocklin, 1998.

[9] Gonçalves de Lima, O. Obtenção direta de 2-hidroxi-1,4naftoquinona a partir de 2-hidroxi-3-(-3-Metil-2-butenil)1,4naftoquinona. Rev. Inst. Antibiót., 1973, 13(1/2), 59-62.

[10] Lee, J.I. B-Lapachone induces growth inhibition and apoptosis in bladder cancer cells by modulation of bcl-2 family and activation of caspases. Exp. Oncol., 2006, 28(1), 30-35.

[11] Santana, C.F.; Lins, L.J.P.; Asfora, J.J.; Melo, A.M.; Gonçalves de Lima, O.; D’Aluquerque, I.L. Primeiras observações com o emprego do Lapachol em pacientes humanos portadores de neoplásias malignas. Rev. Inst. Antibiót., 1980/1, 20(1/2), 61.

[12] Gonçalves de Lima, O. Obtenção de xiloidona (desidrolapachona) por trandformação do lapachol em presença de Pirimidina. Rev. Inst. Antibiót., 1966, 6(1/2), 23-34.

[13] Lee, J.H.; Cheong, J.; Parkym, Choi, Y.H. Down-regulation of cyclooxygenase-2 and telomerase activity by beta-lapachone in human prostate carcinoma cells. Pharmacol. Res., 2005, 51(6), 553.

[14] Matsura, T.; Kai, M.; Fujii, Y.; Ito, H.; Yamada, K. Hydrogen peroxide-induced apoptosis in HL-60 cells requires caspase-3 activation. Free Radic. Res., 1999, 30(1), 73-83

[15] Woo, H.J.; Park, K.Y.; Rhu, C.H. Beta-lapachone, a quinone isolated from Tabebuia avellanedae, induces apoptosis in HepG2 hepatoma cell line through induction of Bax and activation of caspase. J. Med. Food, 2006, 9(2), 161-168

[16] Manna, S.K.; Gad, Y.P.; Mukhopadhyay, A.; Bharat, B. Suppression of tumor necrosis factor-activated nuclear transcription factor$\kappa \mathrm{B}$, activator protein-1, c-Jun $\mathrm{N}$-terminal kinase, and apoptosis by $\beta$-lapachone. Biochem. Pharmacol., 1999, 57(7), 763-774
[17] Oliveira, M.F.; Mattos, L.T.L.G.; Marcos, C. New enamine derivatives of lapachol and biological activity. An. Acad. Bras. Ciênc., 2002, 74(2), 211-221.

[18] Subramanian, S.; Ferreira, M.M.C.; Trsic, M.A. A StructureActivity Relationship Study of Lapachol and Some Derivatives of 1,4-Naphthoquinones Against Carcinosarcoma Walker 256. Struct. Chem., 1998, 9(1), 47- 57.

[19] Balassiano, I.T.; Paulo, S.A. Demonstration of the lapachol as a potential drug for reducing cancer metastasis. Oncol. Rep., 2005, 13(2), 329-33.

[20] De White, N.V.; Stoppani, A.O.M.; Dubin, M. A. 2-Phenyl-betalapachone can affect mitochondrial function by redox cycling mediated oxidation. Arch. Biochem. Biophys., 2004, 432(2), 129-135.

[21] Linardi, M.; da Consolacao, F.; de Oliveira, M. M.; Sapaio, M. R. P. A lapachol derivative against mouse leukemia P-388. J. Med. Chem., 1975, 18, 1159-1164.

[22] Pardee, A.B.; Zhi, L.Y.; Li, C.J. Cancer therapy with betalapachone. Curr. Cancer Drug Targets, 2002, 2(3), 227- 242.

[23] Yoshito, K.; Nobuhiro, S. Possible mechanisms for induction of oxidative stress and suppression of systemic nitric oxide production caused by exposure to environmental chemicals. Environ. Toxicol. Chem., 1997, 3(4), 245.

[24] Gonçalves de Lima, O.; D’Albuquerquer, I.L.; Machado, M.P.; Pinto, G.P.; Maciel, M.G. Uma nova substância antibiótica isolada do Pau D’Arco [abstract]. Anais Soc Biol Pernambuco Brasil Tomo 1956, $X I V(1 / 2) .136$.

[25] Breger, J.; Aperis, G.; Fuchs, B.B.; Moy, T.I.; Ausubel, F.M.; Mylonakis, E. Antifungal chemical compounds identified using a C. elegans pathogenicity assay. PLoS Pathog., 2007, 3(2), 18.

[26] Portillo A., Vila, R.; Freixa, B.; Adzet, T.; Cañigueral, S. Antifungal activity of Paraguayan plants used in traditional medicine, $J$. Ethnopharmacol., 2001, 76(1), 93-98.

[27] Da Silva Júnior, E.N.; de Souza, M.C.; Fernandes, M.C.; MennaBarreto, R.F.; Pinto Mdo, C.; de Assis Lopes, F.; de Simone, C.A.; Andrade, C.K.; Pinto, A.V.; Ferreira, V.F.; de Castro, S.L. Synthesis and anti-Trypanosoma cruzi activity of derivatives from norlapachones and lapachones. Bioorg. Med. Chem., 2008, 16(9), 5030-5038.

[28] Salas, C.; Tapia, R.A.; Ciudad, K.; Armstrong, V.; Orellana, M.; Kemmerling, U.; Ferreira, J.; Maya, J.D.; Morello, A. Trypanosoma cruzi: activities of lapachol and alpha- and beta-lapachone derivatives against epimastigote and trypomastigote forms. Bioorg. Med. Chem., 2008, 16(2), 668-674

[29] Sacau, E.P.; Estévez-Braun, A.; Ravelo, A.G.; Ferro, E.A.F.; Harunkuni, T.; Hoyoku, N. Inhibitory effects of lapachol derivatives on epstein-barr virus activation. Bioorg. Med. Chem., 2003, 11(4), 483-488.

[30] Li, C.J. "Three inhibitors of type 1 human immunodeficiency virus long terminal repeat-directed gene expression and virus replication." Proc. Natl. Acad. Sci. USA, 1993, 90(5), 1839-1842.

[31] Muller, K.; Sellmer, A.; Wiegrebe, W. Potential antipsoriatic agents: lapacho compounds as potent inhibitors of $\mathrm{HaCaT}$ cell growth." Nat. Prod., 1999, 62(8), 1134-1136.

[32] Almeida, E.R.; Silva-Filho, A.A.; Santos, E.R; Lopes, C.A.C. Antiinflammatory Action of Lapachol. J. Ethnopharmacol., 1990, 29(2), 239-241.

[33] Almeida, E.R.; Cesário de Mello, A.; Santana, C.F.; Filho, A.A.S The action of 2-hydroxy-3-(3-methyl-2-butenyl)-1,4-naphtoquinone (Lapachol) in pregnant rats. Rev. Portug Farma, 1988, 38(3), 2123.

[34] Teixeira, M.J.; de Almeida, Y.M.; Viana, J.R.; Holanda Filha, J.G.; Rodrigues, T.P.; Prata, J.R. Jr.; Coêlho, I.C.; Rao, V.S.; Pompeu, M.M. In vitro and in vivo Leishmanicidal activity of 2-hydroxy-3(3-methyl-2-butenyl)-1, 4-naphthoquinone (lapachol). Phytother. Res., 2001, 15(1), 44-48.

[35] Lima, N.M.F.; Correia, C.S.; Leon, L.L.; Machado, G.M.C.; Madeira, M.F.; Santana, A.E.G.; Goulart, M.O.F. Antileishmanial Activity of Lapachol Analogues. I Oswaldo Cruz., 2004, 99(7), 757.

[36] Santos, A.F.; Ferraz, P.A.; De Abreu, F.C.; Chiari, E.; Goulart, M.O.; Sant'ana, A.E. Molluscicidal and trypanocidal activities of lapachol derivatives. Planta Med., 2001, 67(1), 92-93.

[37] Silva, M.N.; Ferreira, V.F.; Souza, M.C.B.V. Overview of the chemistry and pharmacology of naphthoquinones with emphasis on $\beta$-Lapachone and derivatives. Quím. Nova, 2003, 26(3), 407-416.

[38] Fridovich, I. Oxygen toxicity: a radical explanation. J. Exp. Biol., 2001, 61(8), 1203-1209. 
[39] Matés, J.M.; Sánchez-Jiménez, F.M. Role of reactive oxygen species in apoptosis: implications for cancer therapy. Int. J. Biochem. Cell Biol., 2000, 32(2), 157-170.

[40] Do Campo, R.; Cruz, F.S.; Boveris, A.; Muniz, R.P.A.; Darci, M.S.E. $\beta$-lapachone enhancement of lipid peroxidation and superoxide anion and hydrogen peroxide formation by Sarcoma 180 ascites tumor cells. cells. Biochem. Pharmacol., 1979, 28(6), 723728.

[41] McConkey, D.J. Biochemical determinants of apoptosis and necrosis. Toxicol. Lett., 1998, 99, 157-168.

[42] Conrad, D.M.; Robichaud, M.R.; Mader, J.S.; Boudreau, R.T.; Richardson, A.M.; Giacomantonio, C.A.; Hoskin, D.W. 2-Chloro2'-deoxyadenosine-induced apoptosis in T leukemia cells is mediated via a caspase-3-dependent mitochondrial feedback amplification loop. Int. J. Oncol., 2008, 32(6),1325-1333.

[43] Vanni, A.; Fiore, M.; Salvia, R.; Cundari, E.; Ricordy, R.; Ceccarelli, R.; Degrassi, F. DNA damage and cytotoxicity induced by $\beta$-lapachone: relation to poly(ADP-ribose) polymerase inhibition. Mutat. Res., 1998, 401(1-2), 55- 63.

[44] Rover, L.J.R. ; Höehr, N.F.; Vellasco, A. P.; Kubota, L.T. Sistema antioxidante envolvendo o ciclo metabólico da glutationa associado a métodos eletroanalíticos na avaliação do estresse oxidativo. Quím. Nova, 2001, 24(1), 112-119.

[45] Whitacre, C.M.; Zborowska, E.; Gordon, N.H.; Mackay, W.; Berger, N.A. Topotecan Increases Topoisomerase II $\alpha$ Levels and Sensitivity to Treatment with Etoposide in Schedule-dependent Process. Cancer Res., 1997, 57, 1425-1428.

[46] Matés, J.M.; Sánchez-Jiménez, F.M. Role of reactive oxygen species in apoptosis: implications for cancer therapy. Int. J. Biochem. Cell Biol., 2000, 32(2), 157- 170.

[47] Esteves-Souza, A.; Figueiredo, D.V.; Esteves, A.; Câmara, C.A.; Vargas, M.D.; Pinto, A.C.; Echevarria, A. Cytotoxic and DNAtopoisomerase effects of lapachol amine derivatives and interactions with DNA. Braz. J. Med. Biol. Res., 2007, 40, 1399- 1402.

[48] Rahman, I.; Biswas, S.K.; Jimenez, L.A.; Torres, M.; Forman, H.J. Glutathione, stress responses, and redox signaling in lung inflammation. Antioxidant Redox Signal., 2005, 7(1-2), 42-59.

[49] Lima, N.M.F.; Correia, C.S.; Ferraz, P.A.L. Molluscicidal Hydroxynaphthoquinones and Derivatives: Correlation Between their Redox Potentials and Activity Against Biomphalaria glabrata. $J$. Braz. Chem. Soc., 2002, 13(6), 822-829.

[50] Kumi-Diaka, J.; Saddler-Shawnette, S.; Aller, A.; Brown, J. Potential mechanism of phytochemical-induced apoptosis in human prostate adenocarcinoma cells: Therapeutic synergy in genistein and beta-lapachone combination treatment. Cancer Cell Int., 2004, 4, 5.

[51] Kumi-Diaka, J.; Hassanhi, M.; Brown, J.; Merchant, K.; Garcia, C.; Jimenez, W. CytoregR inhibits growth and proliferation of human adenocarcinoma cells via induction of apoptosis. J. Carcinog., 2006, 5,1 .

[52] Tagliarino, C.; Pink, J.J.; Dubyak, G.R.; Nieminen, A.L.; Boothman, D.A. Calcium is a key signaling molecule in beta-lapachonemediated cell death. J. Biol. Chem., 2001, 276(22), 19150.

[53] Rizzuto, R.; Pinton, P.; Aguiari, P.; Blom, T.; Celsi, F.; De Stefani, D.; Fotino, C.; Leo, S.; Marchi, M.; Rimessi, A.; Romagnoli, A.; Siviero, R.; Zecchini, E. Biochim. Biophys. Acta Bioenerg., 2008, 1777(1), S5.

[54] Kumi-Diaka J. Chemosensitivity of human prostate cancer cells PC3 and LNCaP to genistein isoflavone and beta-lapachone. Biol. Cell, 2002, 94(1), 37-44

[55] Ohsawa, S.; Watanabe, T.; Katada, T.; Nishina, H.; Miura, M. Novel antibody to human BASP1 labels apoptotic cells postcaspase activation. Biochem. Biophys. Res., 2008, 371(4), 639-643.

[56] Krishnan, P.; Bastow, F. Novel mechanisms of DNA topoisomerase II inhibition by pyranonaphthoquinone derivatives- eleutherin, $\alpha$ lapachone, and $\beta$ lapachone. Biochem. Pharmacol., 2000, 60(9), 1367.

[57] Wang, J.C. DNA Topoisomerases. Ann. Rev. Biochem., 1996, 65, 635-692.

[58] Vigano, L.; Locatelli, A.; Grasselli, G.; Gianni, L. Drug Interactions of Paclitaxel and Docetaxel and their Relevance for the Design of Combination Therapy. Investigat. New Drugs, 2001, 19(2), 179196.

[59] Li, C.J.; Li, You-Zhi.; Pinto, A.V.; Pardee, A.B. Selective killing of cancer cells by $\beta$-lapachone: Direct checkpoint activation as a strategy against cancer. PNAS, 1999, 96(23), 2675-2678.

[60] Suzuki, M.; Amano, M.; Choi, J.; Williams, B.W.; Ono, K.; Song, C.W. Synergistic effects of radiation and beta-lapachone in DU145 human prostate cancer cells in vitro. Radiat Res., 2006, 165 (5), 525.

[61] Park, H.J.; Bornmann, W.G. J. D.A. Susceptibility of cancer cells to beta-lapachone is enhanced by ionizing radiation. J. Radiat. Oncol.Biol. Phys., 61(1), 212-219.

[62] Wang, H.K.; Xia, Y.; Yang, Z.Y.; Natschke, S.L.; Lee, K.H. Recent advances in the discovery and development of flavonoids and their analogues as antitumor and anti-HIV agents. Adv. Exp. Med. Biol., 1998, 439, 191-225.

[63] Daelemans, D.; Anne-Mieke, V.; De Clercq, E. Human immunodeficiency virus (HIV) gene regulation inhibitors as target for antiviral therapy. Antiviral Chem. Chemother., 1999, 10, 1-14.

[64] Rao, K.V.; McBride, T.J.; Oleson, J.J. Recognition and evaluation of lapachol as an antitumor agent. Cancer Res., 1968, 28, 1952.

[65] Santana, C.F.; Gonçalves Lima, O. Observações sobre as propriedades antitumorais e toxicológicas do extrato do líber e de alguns componentes do cerne do Pau D'Arco (Tabebuia avellanedae). Rev. Inst. Antibiót., 1968, 89(1/2), 89.

[66] Kung, Hsiu-Ni.; Chung-Liang, C.; Gar-Yang, C.; Ming-Jaw, D.; Kuo-Shyan, L.; Yat-Pang, C. Involvement of NO/cGMP signaling in the apoptotic and anti-angiogenic effects of beta-lapachone on endothelial cells in vitro. J. Cell Physiol., 2006, 211(2), 522.

[67] Morrison, R.K.; Brown, D.E.; Oleson, J.J.; Cooney, D.A. Oral toxicology studies with lapachol. Toxicol. Appl. Pharmacol., 1970, 17(1), 1-11.

[68] Ough, M. Efficacy of beta-lapachone in pancreatic cancer treatment: exploiting the novel, therapeutic target NQO1. Cancer Biol. Ther., 2005, 4(1), 95-102.

[69] De Miranda, F.G.; Vilar, J.C.; Alves, I.A.N.; Cavalcanti, S.C.H.; Antoniolli, A.R. Antinociceptive and antiedematogenic properties and acute toxicity of Tabebuia avellanedae Lor. ex Griseb. inner bark aqueous extract." BMC Pharmacol., 2001, l(1), 6.

[70] Böhler, T.; Nolting. J.; Gurragchaa, P.; Lupescu, A.; Neumayer Hans-H.; Budde, K; Kamar, N.; Klupp, J. Tabebuia avellanedae extracts inhibit IL-2-independent T-lymphocyte activation and proliferation. Transplant. Immunol., 2008, 18(4), 319-323.

[71] Nasongkla, N.; Wiedmann, A.F.; Bruening, A.; Beman, M.; Ray, D.; Bornmann, W.G.; Boothman, D.A.; Gao, J. Enhancement of Solubility and Bioavailability of $\beta$-Lapachone Using Cyclodextrin Inclusion Complexes. Pharm. Res., 2003, 20(10), 1626-1633.

[72] Slee, E.A.; Adrain, C.; Martin, S.J. Serial killers: ordering caspase activation events in apoptosis. Cell Death Differ., 1999, 6, 10671074.

[73] Almeida, E.R.; Lucena, F.R.S.; Silva, C.V.N.S.; Costa-Junior, W.S.; Cavalcanti, J.B.; Silva, L.L.S.; Mota, D.L.; Silveira, A.B.; Sousa-Filho, S.D.; Silva, A.C.P. Toxicological assessment of betalapachone on organs from pregnant and non-pregnant rats. Phytothe. Res., 2009, (in press). 